\title{
Seroprevalence of Babesia ovis in small ruminants in Siwa Oasis, Egypt
}

\author{
H. I. Hosein ${ }^{*}$, Samia A. Ahmed ${ }^{2}$, F. A. Ibrahim ${ }^{3}$, T. R. Abou-Elnaga ${ }^{3}$, \\ M. A. Gebely ${ }^{3}$, Mona A. Mahmoud ${ }^{3}$ \\ ${ }^{1}$ Department of Veterinary Medicine, Faculty of Veterinary Medicine, Beni-Suef University, Beni-Suef, Egypt \\ ${ }^{2}$ Department of Veterinary Medicine, Infectious Diseases and Fish, Faculty of Veterinary Medicine, Cairo \\ University, Cairo, Egypt \\ ${ }^{3}$ Department of Animal and Poultry Health, Desert Research Center, Cairo, Egypt
}

\begin{abstract}
Seroprevalence of Babesia ovis in sheep and goats was studied in Siwa Oasis between January 2002 and January 2003. A total of 240 blood samples were collected from 108 sheep and 132 goats for preparation of blood smears and for separation of serum samples and tested against $B$. ovis by using IFAT. B. ovis was detected in $55(50.92 \%)$ and $59(44.69 \%)$ blood smears examined in sheep and goats, respectively. The overall prevalence of $B$. ovis infection was $71.3 \%$ in sheep and $68.2 \%$ in goat using IFAT. The seasonal prevalence of B.ovis peaked in both spring and summer as revealed by blood smear examination and IFAT. A total of 143 ticks were collected from 62 sheep and 81 goats during the study. The ticks examined were Rhipicephalus turanicus $(75.52 \%)$ and Hyalomma anatolicum (24.48\%).
\end{abstract}

Babesia ovis is an intraerythrocytic protozoan parasite that causes babesiosis in sheep and goats. The disease has economic importance in subtropical and tropical regions of the world, Ristic, (1981) and Levine, (1985). It leads to significant losses among small ruminants due to its drastic effect on hemobiotic system, Radostits et al. (2000). Since the indirect immunofluorescence antibody technique (IFAT) has become available for a serological diagnosis and survey of babesiosis, it is possible to test serum samples for babesiosis with high sensitivity.

A number of epidemiological surveys on ovine babesiosis have been reported using IFAT technique in Egypt, (Mahmoud, 1992; AbouElnaga, 2000,2002) however there no literature on ovine babesiosis in Siwa Oasis.

The purpose of this study is to document the presence of B. ovis in Siwa Oasis in order to provide information on the prevalence and intensity of infection in sheep and goats.

\section{Materials and Methods}

Sampling. Blood samples were collected from 108 sheep and 132 goat (aged from three months

\footnotetext{
* Corresponding author. Tel.: +20 10194646; fax: +20 0822327982. (H. I. Hosein).
}

and up to three years) in Siwa Oasis for a period of one year from January 2002 to January 2003 . The animals sampled from each flock were selected randomly. Sera were separated by centrifugation and stored at $-20^{\circ} \mathrm{C}$.

Blood smears. Thin blood smears were prepared from the blood of 108 sheep and 132 goats and examined according to (Kruse and Prichard, 1982).

IFAT. 240 serum samples (108 from sheep and 132 from goats) were tested for antibodies against $B$. ovis antigen. The antigen was prepared according to (Leeflang and Perie, 1972). Whole blood (6\% parasitaemia) was drown into phosphate buffer saline (PBS pH 7.4) in such a proportion that coagulation was prevented $(8 \mathrm{ml}$ blood/100 ml PBS). The mixture was centrifuged and the sediment was washed three times in PBS to free the antigen, the final sediment was restored to the initial blood volume, adjusted by PBS containing $1 \%$ bovine serum albumen to aid in adherence of cells to the microscopic slides. Uniform thin smears, covering the entire surface of a clean microscopic slide, were made and air dried. Masking tap was applied to the dried cell surface, wrapped in groups of five sides in aluminum foil and stored at $-70{ }^{\circ} \mathrm{C}$ until used by 

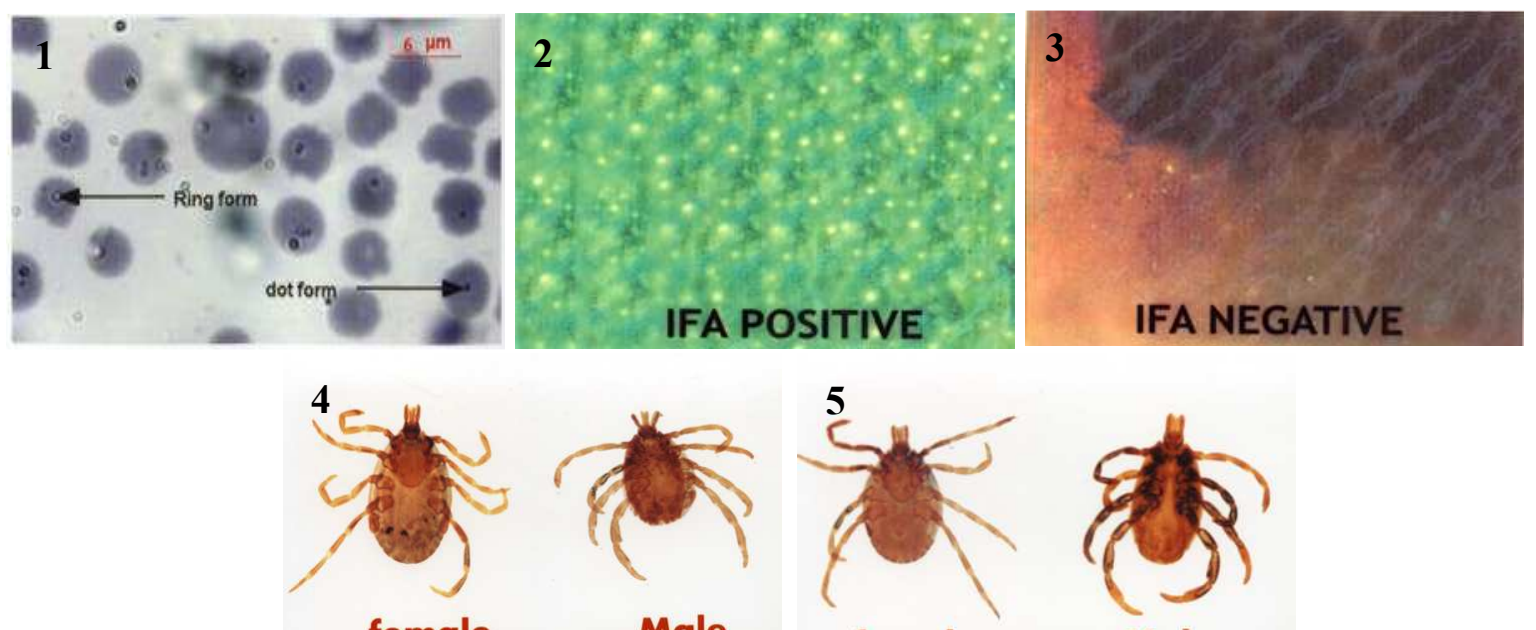

female

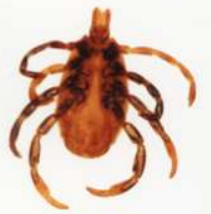

Male

Photo (1): Ring form and dot form of B.ovis in blood film. Photo (2): Negative IFA for B.ovis Photo (3): Positive IFA for B.ovis. Photo (4): Rhipicephalus turanicus female and male ticks collected from sheep and goats. Photo (5): Hyalomma anatolicum female and male ticks collected from sheep and goats.

Table (1): Prevalence of B.ovis infection among sheep using blood film examination.

\begin{tabular}{cccc}
\hline \multirow{2}{*}{ Season } & \multirow{2}{*}{ No. of Examined sheep } & \multicolumn{2}{c}{ Blood film examination } \\
\cline { 3 - 4 } & & 21 & Nositive cases \\
\cline { 3 - 4 } Summer & 41 & 5 & $(51.21 \%)$ \\
Autumn & 11 & 15 & $(45.45 \%)$ \\
Winter & 31 & 14 & $(48.38 \%)$ \\
Spring & 25 & 55 & $(56.00 \%)$ \\
Total & 108 & & $(50.92 \%)$ \\
\hline
\end{tabular}

Table (2): Prevalence of B.ovis infection among goats using blood film examination

\begin{tabular}{cccc}
\hline & & \multicolumn{2}{c}{ Blood film examination } \\
\cline { 3 - 4 } Season & No. of Examined Goats & \multicolumn{2}{c}{ Positive cases } \\
\cline { 3 - 4 } & 19 & 10 & $(52.63 \%)$ \\
\hline Summer & 49 & 17 & $(34.69 \%)$ \\
Autumn & 29 & 13 & $(44.82 \%)$ \\
Winter & 35 & 19 & $(54.28 \%) *$ \\
Spring & 132 & 59 & $(44.69 \%)$ \\
Total & & & \\
\hline
\end{tabular}

* Significant $\mathrm{p} \leq 0.05$ 
Table (3): Prevalence of Babesia ovis infection among sheep using indirect fluorescent antibody test (IFA) in Siwa Oasis.

\begin{tabular}{cccc}
\hline \multirow{2}{*}{ Season } & $\begin{array}{c}\text { No. of Examined sheep } \\
\text { No. }\end{array}$ & \multicolumn{2}{c}{$\begin{array}{c}\text { No. of } \\
\text { positive cases }\end{array}$} \\
\cline { 3 - 4 } & & No. & \% \\
\hline Summer & 41 & 31 & $(75.6 \%)$ \\
Autumn & 11 & 7 & $(63.6 \%)$ \\
Winter & 31 & 20 & $(64.5 \%)$ \\
Spring & 25 & 19 & $(76 \%)$ \\
Total & 108 & 77 & $(71.3 \%)$ \\
\hline
\end{tabular}

Table (4): Prevalence of Babesia ovis infection among goats using indirect fluorescent antibody test (IFA) in Siwa Oasis.

\begin{tabular}{cccc}
\hline \multirow{2}{*}{ Season } & No. of Examined Goats & \multicolumn{2}{c}{$\begin{array}{c}\text { No. of } \\
\text { positive cases }\end{array}$} \\
\cline { 3 - 4 } & & No. & \% \\
\cline { 3 - 4 } Summer & 19 & 14 & $(73.7 \%)$ \\
Autumn & 49 & 32 & $(65.3 \%)$ \\
Winter & 29 & 18 & $(62.1 \%)$ \\
Spring & 35 & 26 & $(64.3 \%)$ \\
Total & 132 & 90 & $(68.2 \%)$ \\
\hline
\end{tabular}

Table (5): Identification of tick species collected from sheep and goats in Siwa Oasis

\begin{tabular}{ccccccccc}
\hline $\begin{array}{c}\text { Total Number of } \\
\text { collected tick } \\
\text { samples }\end{array}$ & \multicolumn{4}{c}{ Sheep } \\
\cline { 2 - 10 } & \multicolumn{2}{c}{$\begin{array}{c}\text { Rhipicephalus } \\
\text { turanicus }\end{array}$} & \multicolumn{1}{c}{$\begin{array}{c}\text { Hyalomma } \\
\text { anatolicum }\end{array}$} & \multicolumn{2}{c}{$\begin{array}{c}\text { Rhipicephalus } \\
\text { turanicus }\end{array}$} & $\begin{array}{c}\text { Hyalomma } \\
\text { anatolicum }\end{array}$ \\
\hline \multirow{2}{*}{$\mathbf{1 4 3}$} & Male & Female & Male & Female & Male & Female & Male & Female \\
& 16 & 26 & 7 & 13 & 21 & 45 & 4 & 11 \\
& $11.18 \%$ & $18.18 \%$ & $4.89 \%$ & $9.09 \%$ & $14.68 \%$ & 31.46 & $2.79 \%$ & $7.69 \%$ \\
\hline
\end{tabular}

IFAT using methods previously described by ( Goff et al., 1982; Tender and Friedhoff, 1988).

Ticks. One hundred and forty three ticks (62 from sheep and 81 from goats) were collected from sheep and goats. Ticks were identified in Prarsitology Department, Faculty of Veterinary Medicine, Cairo University using stereozoom microscope (Olympus) and Hoogstraal keys according to (Hoogstraal, 1956).

\section{Results}

The examination of Giemsa stained blood smears revealed the presence of $B$. ovis piroplasms in 55 sheep (50.92\%) and 59 goats (44.69\%). (Table 1, 2, Photo 1). The seasonal distribution of B. ovis infection peaked in spring $(56 \%)$ and $(54.28 \%)$ in sheep and goats respectively followed by summer $(51.21 \%)$ and $(52.63 \%)$ in sheep and goats respectively. The prevalence of infection between seasons was found to be statistically significant $(\mathrm{p}<0.05)$ according to (Snedecor and Cochram, 1980).

A total of 240 ovine serum samples (108 from sheep and 132 from goats) collected from Siwa Oasis were tested for the presence of antibodies 
against $B$. ovis; 167 samples (77 from sheep and 90 from goats) were found to be positive and the overall prevalence was estimated to be $69.58 \%$ (71.3\% in sheep and $68.2 \%$ in goats). Photo (2) shows negative IFA to B.ovis. Photo (3) shows positive IFAT to B.ovis (Table 3) shows the number of sheep tested and the proportions reacting positively to the IFAT of $B$. ovis antibody in different seasons. Table 4 shows the number of goats tested and the proportions reacting positively to the IFAT of B.ovis antibody in different seasons. The seasonal distribution of B.ovis antibodies peaked in spring ( $76 \%$ and $74.3 \%)$ in sheep and goats respectively followed by summer $(75.6 \%$ and $73.7 \%)$ in sheep and goats, respectively.

One hundred and forty three ticks (62 from sheep and 81 from goats) (Table 5) were examined for the determination of sex and species. Ninety five (39 from sheep and 56 from goats) were found to be female. In terms of species, $75.52 \%$ were Rhipicephalus turanicus $(67.74 \%$ in sheep and $81.48 \%$ in goats), and $24.48 \%$ were Hyalomma anatolicum $(32.26 \%$ in sheep and $18.52 \%$ in goats) photo $(4,5)$. Rhipicephalus turanicus was the predominant species infested both sheep and goats, male Rhipicephalus represented (11.18\% and $14.68 \%$ ) in sheep and goats respectively while female ticks represented $18.18 \%$ in sheep and $31.46 \%$ in goats.

\section{Discussion}

In this study, $50.92 \%$ of sheep and $44.69 \%$ of goats were infected with B.ovis using blood film examination. A higher and lower prevalences were recorded by many authors. Jurasek, (1986) recorded that $48 \%$ of goats were positive for Babesia ovis. Inci et al., (2002) detected Babesia ovis in $17.7 \%$ of sheep and $6.38 \%$ of goats. Razmi et al., (2003) recorded Babesia ovis in 23.5\% from sheep and in $0.5 \%$ in goats. Such variation in the prevalence may be attributed to several factors including difference in localities and consequently difference in climatic conditions which affect the vector activity.

Regarding seasonal variation of prevalence of Babesia ovis using blood film examination in sheep and goats. In the spring, the highest prevalence rate $(56 \%)$ and $(54.28 \%)$ in sheep and goats, respectively was recorded, followed by summer (51.21\%) and (52.63\%) in sheep and goats respectively. Many authors reported that the highest prevalence of Babesia ovis was observed during spring and summer which are considered the seasons of high activity of tick vector, (Rodriguez et al., 1989; Trifonov and Ruseve 1989; Pipano, 1991; Yeruham et al., 1992).

Concerning the serological prevalence of Babesia ovis infection among sheep and goats using IFAT, $71.3 \%$ of the examined sheep and $68.2 \%$ of the examined goats were proved to be positive reactors. Seasonal variation of prevalence of seroreactors of Babesia ovis in sheep and goats showed the same pattern observed by blood smear examination as spring represented the highest prevalence followed by summer, winter and autumn in sheep. In goats spring represented the highest prevalence followed by summer, autumn and winter. IFA has been used by many authors for detection of $B$. ovis among sheep and goats. In Egypt, Mahmoud, (1992) recorded the prevalence of Babesia ovis in sheep in Beni-Suef, El-Sharkia, Kafr El-Shikh and El-Fayoum governorates as $90.9 \%, 88.54 \%, 87.5 \%$ and $86.17 \%$ respectively. Papadopoulos et al. (1996a) recorded Babesia ovis in $52.1 \%$ sheep and $36.4 \%$ goats. Friedhoff (1997) detected Babesia ovis in 50\% sheep and $40 \%$ goats. Karatepe et al. (2003) reported the prevalence of Babesia ovis $34.78 \%$ in goats and $23.63 \%$ in sheep. Variation in the seroprevalence of Babesia ovis infection obtained by different authors and those obtained in this study may be attributed to the geographical and climatic conditions, activity of the vector, parasitic status of the investigated area and immune status of the examined animals (Ferrer et al., 1998).

Concerning the identification of ticks collected from blood parasite infected sheep and goats, the identified tick species were Rhipicephalus turanicus and Hyalomma anatolicum. Similar results were obtained by Trifanov and Ruseve, (1989), Al-Asgah, (1990), Papadopoulos et al. (1996b), Friedhoff, (1997), Yeruham et al. (2000), Abd-El Baky, (2001), Mazyad and Khalaf (2002) and Inci et al. (2003). Babesia ovis has been reported to be transmitted by Rhipicephalus turanicus and Hyalomma anatolicum Yeruham et al. (1992) and Friedhoff, (1997). Climatic conditions particularly temperature, rainfall, 23 ive humidity and the length of the rainy on have been demonstrated as the important factors affecting the life cycle and abundance of ticks, (Mushi et al., 1996 ; Yeruham et al., 1996; 
Yakhchali and Hosseine, 2006).

Concerning the locality of the investigated area, it represents the most suitable conditions favoring the activity of ticks due to the high temperature in such desert area, the presence of cracks in walls and ground and the lack of hygienic conditions necessary for control of ticks. Such conditions clarify the high prevalence of blood parasites among investigated sheep and goats in Siwa Oasis.

In conclusion, the results obtained in this study clarifies that B.ovis is important prevalent pathogen among sheep and goats in Siwa Oasis due to the abundance of the ticks vector as a result of the suitable climatic conditions, poor buildings and lack of sanitations.

\section{References}

Abd El-Baky, S. M. M. (2001): Prevalence of external parasites in the South eastern desert of Egypt. J. Egypt. Soc. Parasitol., 31(1): 223-232.

Abou-EInaga, T. R. (2002): Effects of babesiosis on some serum biochemical parameters in sheep and goats in Matrouh governorate. $10^{\text {th }}$ Sci. Cong. 2002. Fac. Vet. Med, Assiut Univ., Egypt. 235-247.

Abou-Elnaga, T. R. (2000): Some diseases transmitted by ticks in small ruminants Ph.D. Thesis Vet. Sci. Cairo Univ., Egypt.

Al-Asgah, N. A. (1990): Seasonal dynamics of Rhipicephalus turanicus (Acari: Ixodidae) on sheep and goats in the AlSarawat Mountains of Makkah province, Saudi Arabia. Bulletin of the Institute of Zoology Academic Sinica. 29 (2): 113-119.

Ferrer, D.; Castella, J. and Gutierrez, J. F. (1998): Seroprevalence of Babesia ovis in sheep in Catalonia, Northeastern Spain. Vet. Parasitol., 79: 275-281.

Friedhoff, K. T. (1997): Tick-borne diseases of sheep and goats caused by Babesia, Theileria or Anaplasma spp. Parasitologia 639 (2): 99-109.

Goff, W. L.; Wager, G. G.; Ciaic, T. M. and Long, R. F. (1982): The bovine immunoresponse to tick derived Babesia ovis infection. Serological studies of isolated immunoglobulins. Vet. Parasitol., 11 (2-3): 109-120.

Hoogstraal, H. (1956): reference to Equatoria province and with preliminary reviews of the genera Boophilus African Ixodidae 1-Ticks of the Sudan (with special, Margaropus and Hyalomma). Vol. I. U.S. Naval medical researches unit No.3, Cairo, Egypt.

Inci, A.; Karaer, Z. and Ica, A.(2002): Babesiosis in sheep and goats around Kayseri.Saglik - Bilimleri Dergisi, Firat Univ. Vet., 16 (1): 79-83.

Inci, A.; Nalbantoglu, S.; Cam, Y.; Atasever, A.; Karaer, Z.; Cakmak, A.; Sayin, F.; Yukari, B. A.; Ica, A. and Deniz, A. (2003): Theileriosis and tick infestations in sheep and goats around Kayseri.Turk Veterinerlik-ve-HayvancilikDergisi., 27:(1)57-60.

Jurasek, V. (1986): Results of the laboratory examinations of parasitoses in the animals of Mozambique. Folia Veterinaria. 30 (1): 93- 97.
Karatepe, M.; Karatepe, B.; Cakmak, A. and Nalbantoglu, S. (2003): Prevalence of Babesia ovis in sheep and goats in the region of Nigde. Turkiye Parazitoloji dergisi. 27 (1): $18-20$

Kruse, G. O. W. and Prichard, M. H. (1982): The collection and preservation of animal parasites. HwMI, University of Nebraska press, Lincolin, U.S.A.

Leeflang, P. and Perie, N. M. (1972): Comparative immunofluorescent studies on four Babesia species of cattle. Res. Vet. Sci., 13: 342-346.

Levine, D. N.(1985): Veterinary Protozoology. Iowa State University Press, Ames. pp. 413.

Mahmoud, M. S. (1992): Some serological studies on Babesia species infecting sheep in Egypt. M.V.Sc. Thesis, Fac. Vet. Med. Cairo Univ., Egypt.

Mazyad, S. A. M. and Khalaf, S. A. A. (2002): Studies on Theileria and Babesia infecting live and slaughtered animals in Al-Arish and El-Hasanah, North Sinai governorate, Egypt. J. Egypt. Soc. Parasitol., 32 (2): 601-610.

Mushi, E. Z.; Isa, J. F. W. and Sakia, R. M. (1996): Monthly fluctuation of Ixodid tick infestation on indigenous goats in Botswana. Small Rum. Res., 21: 277-279.

Papadopoulos, B.; Michel, B and Perie. N. M. (1996a): Piroplasmosis of domestic animals in the Macedonia region of Greece. Vet. Parasitol., 63: 67-74.

Papadopoulos, B.; Morel, P. C. and Aeschlimann, A. (1996b): Ticks of domestic animals in the Macedonia region of Greece. Vet. Parasitol., 5 (63): 1-2, $25-40$.

Pipano, E. (1991): Observation on the seasonal distribution of blood parasites in sheep in Israel. Israel. J. Vet. Med. , 46 (1): 37-38.

Radostits, O. M.; Gay, C. C.; Blood, D. C. and Hincheliff, K. M. (2000): Veterinary Medicine. $9^{\text {th }}$ ed WH Sounders Co LTD London New York Philadelphia Sydney.

Razmi, G. R.; Naghibi, A.; Aslani, M. R.; Dastjerdi, K. and Hossieni, H. (2003): An epidemiological study on Babesia infection in small ruminants in Mashhad suburb, Khorasan province, Iran. Small Rum. Res., 50: 39-44.

Ristic, M.(1981): Babesiosis. In: Diseases of cattle in the tropics. Ed.: M. Ristic. Martinus Nijhoff Publishers, The Hague, Netherlands,; pp. 443-468.

Rodriguez, O. N.; Rodriguez, P.; Espaine, L. and Rivas, A. (1989): Frequency of haemoparasites in sheep in Cuba. Revista-Cubana de Ciencias Vet., 20 (1): 57-70.

Snedecor, G. W. and Cochran, W. G. (1980): Statistical methods. Oxford \& J.BH Publisihing com. $7^{\text {th }}$. ed.

Tender, A-M. and Friedhoff, K. T. (1988): Serodiagnosis of experimental and natural $B$. equi and $B$. caballi infections. Vet. Parasitol., 20 (1/3): 49-61.

Trifonov, T. and Ruseve,V. (1989): Epizootiologicalstudy of piroplasmosis of cattle, sheep and its ticks vectors in Stangia region of Bulgaria. Veteriinarya Sbirka, 87 (4):43-46.

Yakhchali, M. and Hossein A. (2006): Prevalence and ectoparasites fauna of sheep and goats flocks in Urmia suburb, Iran. Vet. Arhiv., 76: 431-442.

Yeruham, I.; Hadani, A.; Gafker, F. and Rosen, S. H. (1996): The seasonal occurrence of ticks (Acari: Ixodidae) on sheep and in the field in the Judean area of Israel. Exp. App. Acarol., 20: 47 - 65 .

Yeruham, I.; Hadani, A.; Gafker, F. and Rosen, S. H. (2000): Ticks on two flocks of sheep in Israel: prevalence of infestation and corporeal distribution. Ann. Trop. Med. 
Parasitol., 94 (7): 735 - 738.

Yeruham, I.; Hadani, A.; Gafker, F.; Rosen, S. H. and
Schlien, J. (1992): A field study of haemoparasites in two flocks of sheep in Israel. Isr. J. Vet. Med., 47 (3): 107-111.

$$
\text { مسح سيرولوجي لطفيل البابيزيا اوفيز في المجترات الصغيرة بواحة سيوة - مصر }
$$

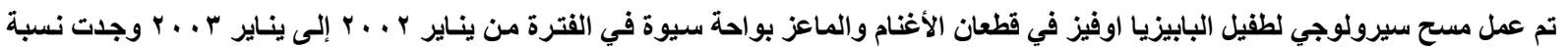

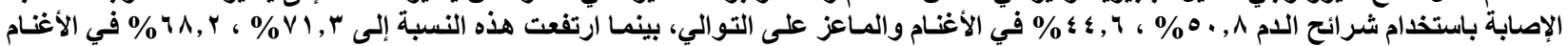

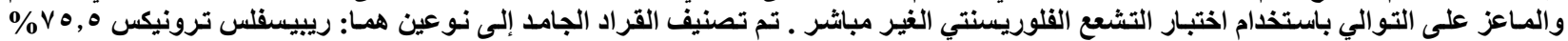
وهيالوما اناتوليكم ع , \& ب \% بمنطقة البحث. 